\title{
Evaluating the Optimum Transplanting Time for Different Coarse Rice Genotypes under Semi-Arid Conditions of Faisalabad
}

\author{
Muhammad Ahtisham Tahir1, Muhammad Ahmad Arain1, Saba Durrani' ${ }^{2}$ Abdul Shakoor', \\ Ahtsham Bilal ${ }^{3}$, Nasir Ali1, Muhammad Ishfaq ${ }^{1 *}$, Umer Farooq ${ }^{4}$, Siraj Ahmed ${ }^{1}$, Muhammad Irfan'
}

${ }^{1}$ Department of Agronomy, University of Agriculture, Faisalabad, Pakistan

${ }^{2}$ Department of Botany, University of Agriculture, Faisalabad, Pakistan

${ }^{3}$ Department of Plant Breeding and Genetics, University of Agriculture, Faisalabad, Pakistan

${ }^{4}$ Department of Plant Breeding and Genetics, Bahauddin Zakariya University, Multan, Pakistan

Email: ishfaq2727@gmail.com

How to cite this paper: Tahir, M.A., Arain, M.A., Durrani, S., Shakoor, A., Bilal, A., Ali, N., Ishfaq, M., Farooq, U., Ahmed, S. and Irfan, M. (2018) Evaluating the Optimum Transplanting Time for Different Coarse Rice Genotypes under Semi-Arid Conditions of Faisalabad. Agricultural Sciences, 9, 69-77. https://doi.org/10.4236/as.2018.91006

Received: November 8, 2017

Accepted: January 14, 2018

Published: January 17, 2018

Copyright $\odot 2018$ by authors and Scientific Research Publishing Inc. This work is licensed under the Creative Commons Attribution International License (CC BY 4.0).

http://creativecommons.org/licenses/by/4.0/

\begin{abstract}
Continuously changing climate and availability of different rice genotypes make it necessary to find optimum time of sowing as well as suitable variety for cultivation to get maximum productivity under a specific set of climatic conditions. A field study was carried out to search out the suitable rice transplanting time for four different coarse genotypes under the semi-arid environment of Faisalabad. The experiment was conducted at Agronomic Research Area, University of Agriculture, Faisalabad and was laid out in randomized complete block design (RCBD) with split plot arrangement keeping transplanting time in main plots while rice genotypes in subplots. Variability among treatments was measured by Fisher's ANOVA $(P \leq 5 \%)$ and LSD test was applied to compare the differences among treatments' means. The ANOVA indicated statistically significant differences among genotypes as well as transplanting dates irrespective of all studied traits while interactive effects of both were found to be non-significant. NIBGE-1 performed best with maximum paddy yield of $6.05 \mathrm{t} / \mathrm{ha}$ while KSK-434 performed poor with paddy yield of $2.78 \mathrm{t} / \mathrm{ha}$. Increased paddy yield and yield related parameters of all rice genotypes were recorded where transplantation was done on $25^{\text {th }}$ of June. Generally, paddy yield decreased with delaying the transplanting time. The results suggested that NIBGE- 1 can perform better under the semi-arid conditions of Faisalabad and last week of June might be the optimum time for nursery transplantation. It can also be further elucidated that late transplanting
\end{abstract}


causes yield reduction which could not be recommended among farmers.

\section{Keywords}

Coarse Rice, Genotypes, Transplanting Time, Paddy Yield, Semi-Arid

\section{Introduction}

Rice (Oryza sativa L.) is the major crop in after wheat that feeds about half of the world and its share of Asian countries is $75 \%$ in total global rice production [1]. Rice covers about 150 million hectares of land [2]. In Asia, it is the main dietary item of 3.5 billion people [3]. Therefore, increase in population will require 70 percent more rice in 2025 than it is consumed today [4]. Asia produces and consumes a huge part (90\%) of world's rice [5]. Production of high quality basmati rice with good aroma achieves the domestic demand and also for exports [6]. Pakistan earned US $\$ 1.53$ billion in rice exports and it contributes 3.2\% in the value addition in agriculture and $0.7 \%$ of GDP [7]. Every day increasing urbanization and population in cities and villages increases the demand and consumption of rice worldwide [8].

Among the different factors that are involved in decreasing the actual economic return than the potential of that genotype, less application of input, improper and poor management practices for obtaining economic yield such as lower plant population, defective application strategies and time of fertilizer and sowing time are the most imperative [9]. The age of seedling to be transplanted from nursery to field is one of the factors because early or late transplanting may face various types of a-biotic stresses. Rice plants require optimal temperature for anthesis, panicle emergence, panicle exertion from flag leaf sheath, maturity and almost all these phenological measures are highly influenced by the transplanting date and age of seedling [10].

Time of transplanting also influences grain yield and a decline in rice yield was reported by delayed transplanting [11]. The optimum sowing date in direct seeded rice (DSR) plays a critical role due to three major reasons: improved vegetative growth, mitigation of low temperature stress and improved grain filling [12]. Early transplanting in rice increased tillering, plant height, grain weight and yield due to prolonged vegetative growth period [13]. Khakwani [14] also determined that rice transplanted from nursery to field at young seedling stages improves paddy yield, increases plant height and more grain straw ratio so, early transplanting is the only way to improve grain yield.

Bashir et al. [3] suggested that for coarse rice varieties the optimum sowing date is the key factor for getting maximum net income and yield as well as delay in sowing gradually reduces the yield. The present study was carried out to find the suitable time for transplanting of course rice from nursery to field under the 
semi-arid situation and to evaluate the best performing genotypes for future recommendations.

\section{Materials and Methods}

\subsection{Experimental Site, Design and Treatments}

Purposed study was conducted in field at the Agronomic Research Area, University of Agriculture, Faisalabad, during Kharif season 2015 to evaluate the feasible transplanting time under conditions of Faisalabad for the coarse rice transplantation. The experiment was laid out in randomized complete block design (RCBD) in split plot arrangement having three replications. Net size of experimental unit was $2.25 \mathrm{~m} \times 4 \mathrm{~m}$ and seedlings were planted at $22.5 \mathrm{~cm}$ row to row and plant to plant distance. The experiment was comprised of two factors: main plot factor was transplanting dates as $25^{\text {th }}$ of June, $10^{\text {th }}$ of July, $25^{\text {th }}$ of July and $10^{\text {th }}$ of August while the second factor was coarse rice genotypes as KSK-434, KSK-133, NIBGE-1 and NIBGE-2.

\subsection{Fertilization, Irrigation and Nursery Raising}

Fertilizer was applied at (125:75:65 kg/ha N:P:K) using urea, diammonium phosphate (DAP) and sulphate of potash (SOP) as a source of fertilizer. Whole quantity of DAP, SOP and $1 / 3$ of Urea were applied at the time of transplanting and remaining two doses of nitrogen were applied at two critical stages i.e. tillering and panicle initiation. Recommended dose of Zinc@12.5 kg/ha in the form of $\mathrm{ZnSO}_{4}$ was applied 20 days after transplanting. Total 16 irrigations (each of 4 -acre inch depth) were applied, at seedling stage $5-6 \mathrm{~cm}$ water depth and at lateral stages $3 \mathrm{~cm}$ depth of water were maintained in the experimental field.

Keeping in mind four different transplanting dates, four nurseries of rice were sown which were transplanted at the seedling stage of 30 days. Manual one month old rice seedlings were transplanted in 4th week of June to the 2nd week of August with an interval of 15 days. Nursery was transplanted in standing water conditions to avoid seedling mortality and for successful seedling establishment. The missing hills were replanted within a week after transplanting. While, other factor like nutrient status of experimental plot was homogeneous. Weather data of the crop growth period is represented in Figure 1.

\subsection{Data Collection and Analysis}

An area of $1 \mathrm{~m}^{2}$ (two replicates from each plot) was selected randomly from each plot and total number of tillers, total number of productive tillers and number of non-productive tillers were counted manually at the time of harvest maturity. The data were recorded from selected plants regarding plant height $(\mathrm{cm})$, panicle length $(\mathrm{cm})$ and branches/panicles was measured and then averaged. Data regarding 1000-kernel weight (g) from each treatment was recorded in grams using an automatic electric balance. The biological yield $(\mathrm{t} / \mathrm{ha})$ of each experimental 


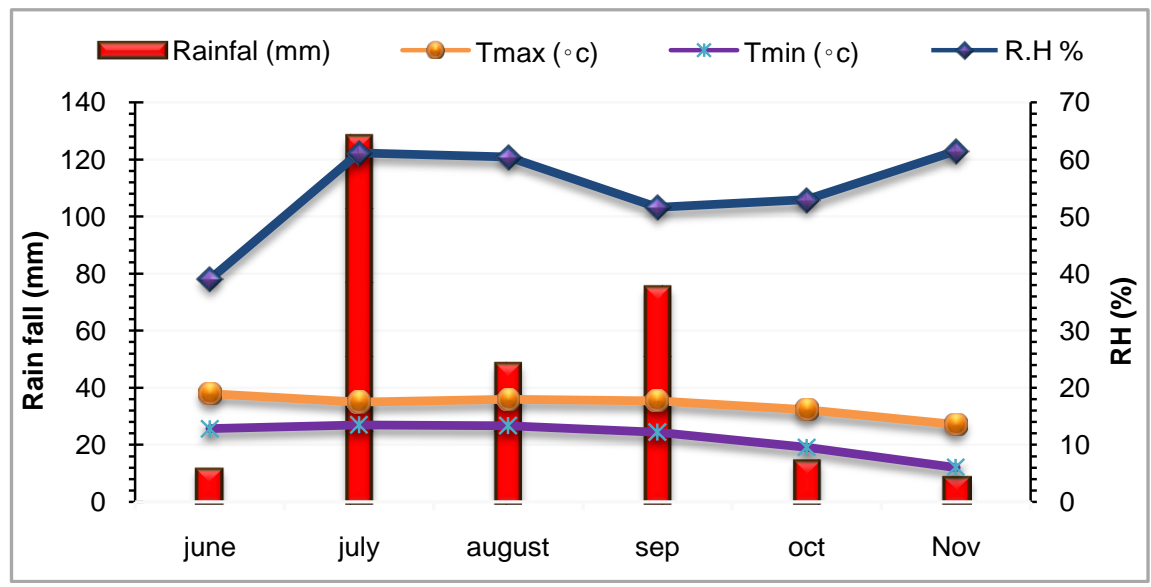

Figure 1. Maximum and minimum temperature $\left({ }^{\circ} \mathrm{C}\right)$, Rainfall $(\mathrm{mm})$ and Relative humidity (\%) over the growing period of rice.

unit was weighed after harvesting the crop. After harvesting and threshing the clean rough (paddy) rice was air dried, bulked and weighed to record the kernel yield $(\mathrm{t} / \mathrm{ha})$. The harvest index was calculated as the ratio of grain yield to total (above ground) biological yield using the formula: $\mathrm{HI}=$ Economic yield/Biological yield $\times 100$. Data collected was analyzed Fishers' analysis of variance and treatments means were compared by LSD test at probability level of $5 \%$ [15].

\section{Results}

Fisher's analysis of variance of data recorded revealed statistically significant variations among the transplanting time for all measured parameters but non-significant for biological yield. The variation among the coarse rice genotypes was also statistically significant for all measured parameters but non-significant for harvest index. However, interaction between transplanting time and coarse rice genotypes was found statistically non-significant. The results showed that plant height decreased as transplanting time prolonged among all rice genotypes. The maximum plant height $(76.95 \mathrm{~cm})$ was observed in first transplanting date ( $25^{\text {th }}$ of June) (Table 1$)$. However, it remained statistically at par with all other transplanting dates except last one which was $10^{\text {th }}$ of August. The minimum plant height $(73.20 \mathrm{~cm})$ was noted in those plots that were transplanted on $10^{\text {th }}$ of August (Table 1$)$. The maximum plant height $(80.05 \mathrm{~cm})$ was recorded by NIBGE-1 cultivar and it remained statistically at par with NIBGE-2 and KSK-133. However, the minimum plant height $(71.43 \mathrm{~cm})$ was noted in KSK-434 (Table 1).

Non-productive tillers significantly increased with delay in transplanting. The maximum number of tillers (324.92) and productive tillers $(293.83) / \mathrm{m}^{2}$ were observed in third transplanting date $\left(25^{\text {th }}\right.$ of July) (Table 1$)$. However, it remained statistically at par with $10^{\text {th }}$ of August transplanting date. The minimum tillers (265.83) and productive tillers $(240.50) / \mathrm{m}^{2}$ were noted in those plots that were transplanted on $25^{\text {th }}$ of June and it was statistically similar with 
Table 1. Effect of different sowing dates on the yield and productivity of various coarse rice genotypes under semi-arid conditions of Faisalabad.

\begin{tabular}{|c|c|c|c|c|c|c|c|c|c|c|c|}
\hline \multicolumn{2}{|c|}{ Treatments } & $\begin{array}{l}\text { Plant } \\
\text { height }\end{array}$ & $\begin{array}{l}\text { Total } \\
\text { tillers }\end{array}$ & $\begin{array}{c}\text { Productive } \\
\text { tillers }\end{array}$ & $\begin{array}{c}\text { Non-productive } \\
\text { tillers }\end{array}$ & $\begin{array}{c}\text { Branches/ } \\
\text { panical }\end{array}$ & $\begin{array}{l}\text { Panicle } \\
\text { length }\end{array}$ & $\begin{array}{c}\text { 1000-kernel } \\
\text { weight }\end{array}$ & $\begin{array}{l}\text { Paddy } \\
\text { yield }\end{array}$ & $\begin{array}{l}\text { Biological } \\
\text { yield }\end{array}$ & $\begin{array}{c}\text { Harvest } \\
\text { index }\end{array}$ \\
\hline & & $(\mathrm{cm})$ & $\left(/ \mathrm{m}^{2}\right)$ & $\left(/ \mathrm{m}^{2}\right)$ & $\left(/ \mathrm{m}^{2}\right)$ & (count) & $(\mathrm{cm})$ & (g) & $(\mathrm{t} / \mathrm{ha})$ & (t/ha) & (\%) \\
\hline \multirow{4}{*}{$\begin{array}{c}\text { Transplantin } \\
\text { time }\end{array}$} & $\begin{array}{l}25^{\text {th }} \text { of } \\
\text { June }\end{array}$ & $76.95 \mathrm{a}$ & $265.83 \mathrm{~b}$ & $240.50 \mathrm{~b}$ & $25.33 \mathrm{~d}$ & $14.75 \mathrm{a}$ & $20.63 \mathrm{a}$ & $94.85 \mathrm{a}$ & $4.55 \mathrm{a}$ & 16.75 & $35.48 \mathrm{a}$ \\
\hline & $\begin{array}{l}10^{\text {th }} \text { of } \\
\text { July }\end{array}$ & $76.23 \mathrm{ab}$ & $272.08 \mathrm{~b}$ & $244.00 \mathrm{~b}$ & $28.08 \mathrm{c}$ & $13.91 \mathrm{ab}$ & $19.63 \mathrm{~b}$ & $91.58 \mathrm{~b}$ & $4.36 \mathrm{~b}$ & 16.46 & $34.50 \mathrm{a}$ \\
\hline & $\begin{array}{c}25^{\text {th }} \text { of } \\
\text { July }\end{array}$ & $74.55 \mathrm{ab}$ & $324.92 \mathrm{a}$ & $293.83 \mathrm{a}$ & $31.08 \mathrm{~b}$ & $12.83 \mathrm{~b}$ & $19.38 \mathrm{c}$ & $88.54 \mathrm{c}$ & $4.20 \mathrm{c}$ & 16.04 & $34.50 \mathrm{a}$ \\
\hline & $\begin{array}{l}10^{\text {th }} \text { of } \\
\text { Aug }\end{array}$ & $73.02 \mathrm{~b}$ & $305.50 \mathrm{ab}$ & $270.00 \mathrm{ab}$ & $35.50 \mathrm{a}$ & $11.25 \mathrm{c}$ & $18.88 \mathrm{~d}$ & $86.12 \mathrm{~d}$ & $3.52 \mathrm{~d}$ & 15.78 & $31.90 \mathrm{~b}$ \\
\hline \multicolumn{2}{|c|}{ LSD value } & 3.57 & 43.97 & 43.69 & 0.90 & 1.43 & 0.24 & 1.82 & 0.24 & NS & 1.35 \\
\hline \multirow{4}{*}{$\begin{array}{c}\text { Rice } \\
\text { genotypes }\end{array}$} & KSK-434 & $71.43 c$ & $253.75 \mathrm{c}$ & $217.83 c$ & $35.91 \mathrm{a}$ & $10.91 \mathrm{~d}$ & $15.50 \mathrm{~d}$ & $74.23 \mathrm{~d}$ & $2.78 \mathrm{~d}$ & $11.69 c$ & 30.68 \\
\hline & KSK-133 & $73.53 \mathrm{bc}$ & $274.08 \mathrm{bc}$ & $244.50 \mathrm{bc}$ & $29.58 \mathrm{~b}$ & $12.25 \mathrm{c}$ & $17.75 \mathrm{c}$ & $83.67 \mathrm{c}$ & $3.20 \mathrm{c}$ & $12.15 \mathrm{c}$ & 31.62 \\
\hline & NIBGE-1 & $80.05 \mathrm{a}$ & $337.50 \mathrm{a}$ & $312.42 \mathrm{a}$ & $29.41 \mathrm{~b}$ & $16.00 \mathrm{a}$ & $19.30 \mathrm{~b}$ & $109 \mathrm{a}$ & $6.05 \mathrm{a}$ & $26.61 \mathrm{a}$ & 39.29 \\
\hline & NIBGE-2 & $75.7 \mathrm{~b}$ & $303.00 \mathrm{ab}$ & $273.58 \mathrm{ab}$ & $25.08 \mathrm{c}$ & $13.58 \mathrm{~b}$ & $25.98 \mathrm{a}$ & $93.88 \mathrm{~b}$ & $4.60 \mathrm{~b}$ & $14.58 \mathrm{~d}$ & 34.79 \\
\hline \multicolumn{2}{|c|}{ LSD value } & 3.48 & 40.03 & 39.01 & 2.78 & 0.79 & 1.03 & 3.11 & 0.41 & 2.37 & NS \\
\hline \multicolumn{2}{|c|}{ Interaction } & \multicolumn{10}{|c|}{ Non-significant } \\
\hline
\end{tabular}

Values sharing the different letters differ significantly at $P \leq 0.05$, NS $=$ Non-Significant.

second transplanting date ( $10^{\text {th }}$ of July) (Table 1$)$. The maximum number of non-productive tillers $(35.50) / \mathrm{m}^{2}$ was observed in fourth transplanting date $\left(10^{\text {th }}\right.$ of August) followed by $25^{\text {th }}$ of July transplanting date which gave 31.08 non-productive tillers (Table 1). The least numbers of non-productive tillers $(25.33) / \mathrm{m}^{2}$ were noted in those plots that were transplanted on $25^{\text {th }}$ of June (Table 1). The maximum tillers (337.50) and productive tillers $(312.42) / \mathrm{m}^{2}$ were recorded by NIBGE-1 cultivar and it remained statistically at par with NIBGE-2. However, the minimum tillers (253.75) and productive tillers $(217.83) / \mathrm{m}^{2}$ were noticed in KSK-434 (Table 1). The maximum non-productive tillers $(35.91) / \mathrm{m}^{2}$ were recorded in KSK-434 cultivar followed by KSK-133 and the minimum non-productive tillers $(25.08) / \mathrm{m}^{2}$ were noticed in NIBGE-2 cultivar (Table 1 ).

The number of branches/panicle, panicle length decreased as the transplanting time prolonged. The maximum number of branches/panicle (14.75) and panicle length $(20.63 \mathrm{~cm})$ were observed in first transplanting date $\left(25^{\text {th }}\right.$ of June) followed by transplanting time of $10^{\text {th }}$ of July (Table 1). However, the number of branches/panicle in $25^{\text {th }}$ of June and $10^{\text {th }}$ of July were statistically at par. The lowest numbers of branches/panicle (11.25) and panicle length $(18.88 \mathrm{~cm})$ were noted in those plots that were transplanted on $10^{\text {th }}$ of August (Table 1). The maximum branches/panicle (16.00) were recorded by NIBGE-1 cultivar followed by NIBGE-2 and the minimum branches/panicle (10.91) were noticed in KSK-434 cultivar. The maximum panicle length $(25.98 \mathrm{~cm})$ was recorded by NIBGE-2 cultivar followed by NIBGE-1 while the minimum panicle length 
$(15.50 \mathrm{~cm})$ was seen in KSK-434 cultivar (Table 1 ).

The paddy yield and grain weight decreased significantly as transplanting time delayed. The maximum paddy yield (4.55 t/ha) and 1000-kernel weight (94.85 g) was observed in first transplanting date $\left(25^{\text {th }}\right.$ of June) followed by transplanting on $10^{\text {th }}$ of July (Table 1$)$. The minimum paddy yield (3.52 t/ha) and 1000-kernel weight $(86.12 \mathrm{~g})$ observed in those plots that were transplanted on $10^{\text {th }}$ of $\mathrm{Au}$ gust. Harvest index also decreased as transplanting prolonged. The maximum harvest index (35.48\%) was observed in first transplanting date ( $25^{\text {th }}$ of June) and it remained statistically at par with other transplanting dates except last one $\left(10^{\text {th }}\right.$ of August) (Table 1). The minimum harvest index (31.90\%) was observed in those plots that were transplanted on $10^{\text {th }}$ of August (Table 1). Statistically significant variation was recorded among the biological yield of different rice genotypes but the harvest index was not significantly varied. The maximum 1000-kernel weight (109 g) was recorded in NIBGE-1 cultivar followed by NIBGE-2 (Table 1). However, the minimum 1000-kernel weight (74.23 g) was noticed in KSK-434 cultivar. Among the genotypes, the maximum paddy yield (6.05 t/ha) and biological yield (26.61 t/ha) was recorded by NIBGE-1 cultivar followed by NIBGE-2 (Table 1 ). However, the minimum paddy yield ( $2.78 \mathrm{t} / \mathrm{ha}$ ) and biological yield (11.69 t/ha) was noticed in KSK-434 cultivar. However, the minimum biological yield (11.69 t/ha) in KSK-434 cultivar remained statistically at par with KSK-133 (Table 1).

\section{Discussion}

In the current study, it is obvious that transplanting times have influenced the most of yield contributing components of coarse rice genotypes, substantially. Among transplanting dates, June $25^{\text {th }}$ planted crop produced higher 1000-kernel weight and paddy yield. While in the case of genotypes, NIBGE-1 performed better under agro-climatic conditions of Faisalabad. From the analysis of data, it is recommended that NIBGE-1 as coarse rice cultivar should be planted in end of June in order to obtain higher productivity under semi-arid environment of Faisalabad.

The genetic makeup of NIBGE-1 cultivar might have assisted it to perform well as compared to other cultivars. The possible reason for the difference in plant height in rice genotypes is genetic makeup. This result is in line with those reported by Ameen et al. [16] who reported significant difference in rice height due to different rice genotypes. However, interactive effect of transplanting dates and rice genotypes on plant height was statistically not similar. Plant height is a function of combined effects of genetic makeup of a plant, seed vigor, soil nutrient status and ecological conditions. Similarly, other possible reason for decreased in plant height is that average of minimum and maximum temperature predominant during seedling growth stage increased with delay in nursery sowing. Baloch et al. [17] and Safdar et al. [18] also observed increased in total number of tillers and productive tiller $/ \mathrm{m}^{2}$ with delay in transplanting time from 
month of June. Higher total and productive tillers with delay in transplanting might be due to comparatively low temperature, high rainfall and humidity. The plants of late transplanted rice faced temperature free conditions during seedling stage however, high temperature stress during reproductive phase. So, this is the possible reason for increase in non-productive tiller $/ \mathrm{m}^{2}$ with delay in transplanting. The tillering potential of rice is being controlled by specific genes, hormones and environmental conditions [19]. Li et al. [20] identified first gene responsible for tillering in rice no italic MOC1. The possible reason of higher production of tiller by NIBGE-1 is the result of over expression of tillering controlling gene (MOC1) under a favorable environment. Similarly, lower tiller $/ \mathrm{m}^{2}$ in KSK-434 are related with less expression of MOC1 due to presence of plant inhibitors of this gene. Branches/panicle ${ }^{a}$ and panicle length are genetic characters but also influenced by environmental factors. Delay in transplanting would decrease the length of growing season which ultimately resulted in reduction of branches/panicle and panicle length [18]. Likewise, late transplanted rice confronted temperature stress free conditions during early seedling stage but high temperature stress during reproductive phase. This is also a possible reason of decrease in branches/panicle and panicle length with delay in transplanting time. The 1000-seed weight is a very important trait for determining the grain yield of the crop. The 1000-kernel weight in rice is a genetic controlled trait and variety-specific attribute [21] and least influenced by environment [17]. Maximum grain weight was produced by rice seedlings that were transplanted on $15^{\text {th }}$ of July [14]. The early transplanted rice produced more photosynthates due to more interception of radiations and resultantly more accumulation of assimilates in kernels/grains gave heavier grains and high paddy yield. However, delay in transplanting would decrease the length of growing season which ultimately resulted in reduction of paddy yield due to lower production assimilates. Likewise, late transplanted rice confronted temperature stress free conditions during early seedling stage but high temperature stress during reproductive phase. This high temperature during reproductive phase shortened the grain filling period so that low paddy yield was resulted. Numerous transplanting dates and nitrogen levels significantly influences the yield and yield-contributing traits. Optimum transplanting date approximately enhanced greater than $10 \mathrm{t} / \mathrm{ha}$ paddy yields [22]. Early transplanted rice utilized the resources efficiently and produced high economic and biological yield ultimately higher harvest index. Harvest index was significantly affected by transplanting dates and varieties [23]. Enhanced grain and straw ratio is might be due to the healthier and optimum plant population, plant height, augmented crop growth rate (CGR) and net assimilation rate (NAR) which finally enhanced harvest index. In contrast, harvest index in rice was not significantly affected by planting date as reported by Soleymani and Shahrajabian, [24]. The difference in paddy yield of rice genotypes might be attributed with comparatively high genetic potential of NIBGE-1 cultivar. This cultivar also produced more yield contributing components and resultantly, 
higher paddy yield was observed. Total biomass production and its dispersal between grain and straw yield is a concern for the appraisal of crop performance. It mainly depends on crop growth rate of a crop which regulates the maturity timing of the crop [25].

\section{Conclusion}

In nut shell, delayed sowing and transplanting of rice hampered the rice panicle length, test weight and yield significantly. Last week of June is optimum for transplanting coarse rice varieties. While using newly approved varieties with high yield genetic potential like NIBGE-1 cultivar enhances yield and profitability under conventional rice production system of rice.

\section{References}

[1] Lindnera, S., Xuea, W., Nay-Htoonb, B., Choic, J., Egea, Y., Lichtenwalda, N., Fischera, F., Koc, J., Tenhunena, J. and Otienoa, D. (2016) Canopy Scale $\mathrm{CO}_{2} \mathrm{Ex}-$ change and Productivity of Transplanted Paddy and Direct Seeded Rainfed Rice Production Systems in S. Korea. Agricultural and Forest Meteorology, 228, 229-238. https://doi.org/10.1016/j.agrformet.2016.07.014

[2] Bouman, B.A.M., Lampayan, R.M. and Tuong, T.P. (2007) Water Management in Irrigated Rice: Coping with Water Scarcity. International Rice Research Institute, Los Banos (Philippines), $54 \mathrm{p}$.

[3] Bashir, M.U., Akber, N., Iqbal, A. and Zaman, H.Z. (2010) Effect of Different Sowing Dates Yield and Yield Components of Direct Seeded Coarse Rice (Oryza sativa L.). Pakistan Journal of Agricultural Sciences, 47, 361-365.

[4] Kim, J.K. and Krishnan, H.B. (2002) Making Rice a Perfect Food: Tuning Dreams into Reality. Journal of Crop Production, 5, 93-130. https://doi.org/10.1300/J144v05n01_05

[5] Said, A., Zada, A. and Tahir, M. (2003) Improved Cultural Practices for Profitable Rice Production in North West Frontier Province. TASRAN Computer Associate, Mingora, Swat, Pakistan.

[6] Shahbaz, M., Rasul, F., Saghir, A., Junaid, M.B., Mahmood, A. and Ahmad, M. (2015) Bio-Economics and Radiation Use Efficiency of Basmati, Hybrid and Coarse Rice (Oryza Sativa L.) Varieties. International Journal of Research in Agriculture and Forestry, 2, 6-13.

[7] Govt. of Pakistan (2015) Economic Survey of Pakistan 2014-2015. Finance Division, Economic. Advisory Wing, Islamabad, Pakistan, $21 \mathrm{p}$.

[8] Mishra, A. and Salokhe, V.M. (2009) Seedling Characteristics and the Early Growth of Transplanted Rice under Different Water Regimes. International Journal of EXperimental Agriculture, 44, 365-383.

[9] Ashraf, U., Anjum, S.A, Ehsanullah, K.I. and Tanveer M. (2014) Planting Geometry Induced Alteration in Weed Infestation, Growth and Yield of Puddled Rice. Pakistan Journal of Weed Sciences Research, 20, 77-89.

[10] BRRI (Bangladesh Rice Research Institute) (1989) Annual Internal Review for 1988. Plant Physiology Division, Bangladesh Rice Research Institute, Gazipur, Bangladesh, $59 \mathrm{p}$.

[11] Arora, V.K., Gajri, P.R. and Uppal, H.S. (2006) Puddling, Irrigation, and Transplanting-Time Effects on Productivity of Rice-Wheat System on a Sandy Loam Soil 
of Punjab, India. Soil \& Tillage Research, 85, 212-220. https://doi.org/10.1016/j.still.2005.01.015

[12] Farrell, T.C., Fox, K., Williams, R.L., Fukai, S. and Lewin, L.G. (2003) Avoiding Low Temperature Damage in Australia's Rice Industry with Photoperiod Sensitive Cultivars. Proceedings of the 11 th Australian Agronomy Conference, Deakin University, Geelong, Victoria, Australia, 2-6 Feb. 2003.

[13] Khalifa, A.A.B.A. (2009) Physiological Evaluation of Some Hybrid Rice Varieties under Different Sowing Dates. Australian Journal of Crop Science, 3, 178-183.

[14] Khakwani, A.A., Zubair, M., Mansoor, M., Naveed, K., Shah, I.H., Wahab, A., llyas, M. and Ahmed, I. (2006) Agronomic and Morphological Parameters of Rice Crop as Affected by Date of Transplanting. Journal of Agronomy, 5, 248-250. https://doi.org/10.3923/ja.2006.248.250

[15] Steel, R.G.D., Torrie, J.H. and Dickey, D. (1997) Principles and Procedures of Statistics: A Biometrical Approach. $3^{\text {rd }}$ Edition, McGraw Hill Book Co. Inc., New York, 172-177.

[16] Ameen, A., Aslam, Z., Zaman, Q., Ullah, E., Zamir, S.I., Khan, I. and Subhani, M.J. (2014) Performance of Different Cultivars in Direct Seeded Rice (Oryza sativa L.) with Various Seeding Densities. American Journal of Plant Sciences, 5, 3119-3128. https://doi.org/10.4236/ajps.2014.521328

[17] Baloch, M.S., Ullah, A.I. and Gull, H. (2006) Growth and Yield of Rice as Affected by Transplanting Dates and Seedlings/Hill under High Temperature of Dera Ismail Khan, Pakistan. Journal of Zhejiang University Science, 7, 527-579. https://doi.org/10.1631/jzus.2006.B0572

[18] Safdar, M.E., Noorka, I.R., Tanveer, A., Tariq, S.A. and Rauf, S. (2013) Growth and Yield of Advanced Breeding Lines of Medium Grain Rice as Influenced by Different Transplanting Dates. Journal of Animal and Plant Sciences, 23, 227-231.

[19] Hussien, A., Tavakol, E., Horner, D.S., Amatriain, M.M., Muehlbauer, G.J. and Rossini, L. (2014) Genetics of Tillering in Rice and Barley. Plant Genome, 16, 256-275. https://doi.org/10.3835/plantgenome2013.10.0032

[20] Li, X.Y., Qian, Q., Fu, Z.M., Wang, Y.H., Xiong, G.S., Zeng, D.L., Wang, X.Q., Liu, X.F., Teng, S., Hiroshi, F., Yuan, M., Luo, D., Han, B. and Li, J.Y. (2003) Control of Tillering in Rice. Nature, 422, 618-621. https://doi.org/10.1038/nature01518

[21] Jalilian, J., Modarres, S.A.M. and Sabaghpour, S.H. (2005) Effect of Plant Density and Supplemental Irrigation on Yield, Yield Components and Protein Content of Four Chickpea (Cicer arietinum L.) Cultivars under Dry Land Condition. Journal of Agricultural Sciences and Natural Resources, 12, 32-41.

[22] Abid, M., Khan, I., Mahmood, F., Ashraf, U., Imran, M. and Anjum, S.A. (2015) Response of Hybrid Rice to Various Transplanting Dates and Nitrogen Application Rates. The Philippine Agricultural Scientist, 98, 98-104.

[23] Vashisht, B.B., Jalota, S.K. and Vashist, K.K. (2015) Yield, Water Productivity and Economics of Rice (Oriza sativa L.) as Influenced by Transplanting Dates, Varieties and Irrigation Regimes in Central Punjab. Indian Journal of Agronomy, 60, 65-69.

[24] Soleymani, A. and Shahrajabian, M.H. (2011) The Influence of Different Planting Dates, Plant Densities on Yield and Yield Components of Rice on the Basis of Different Nitrogen Levels. International Journal of Plant Production, 2, 80-83.

[25] Bange, M.P. and Milory, S.P. (2001) Growth and Dry Matter Partitioning of Diverse Cotton Genotypes. Field Crops Research, 87, 73-87.

https://doi.org/10.1016/j.fcr.2003.09.007 